\title{
Assessment process of concept for mining and its impact on the region
}

\author{
Michal Cehlár ${ }^{1, *}$, Juraj Janočko ${ }^{1}$, Zuzana Šimková ${ }^{1}$, and Tomas Pavlik ${ }^{1}$ \\ ${ }^{1}$ Technical University of Kosice, Faculty of Mining, Ecology, Process Control and Geotechnologies, \\ Letná 9, 04200 Kosice, Slovak republic
}

\begin{abstract}
Raw materials policy of the Slovak republic is currently in stage of the stagnation due to complex conception and outdated data (not updated from 2003). Nowadays there is an effort of the state to develop a completely new concept of the raw material policy using best available techniques in the given field. Paper is based on the study case of assessment of regional impacts of mining and processing the gold ore to public finance derived from real contitions of the Slovak republic region. Results achieved originates from the models for the assessment of the project of mining as well as from the model of environmental and social impact assessment. The main aim of the contribution is to increase the effectiveness in raw materials using with regard to environmental and social impact of the assessed region which could be implemented to the raw materials policy on the national level.
\end{abstract}

\section{Introduction}

The raw material policy of the Slovak republic reflects the all-society interest are essential for the sustainable functioning of modern societies [8]. Criticality of different metallic and mineral raw materials has gained attention in recent years. Consequently, the systematic evaluation of raw material criticality has been the subject of numerous studies in recent years [9]. Several working groups around the world have made criticality assessments for raw materials to analyze the driving impact factors for the instability [10]. Access and affordability of mineral raw materials are crucial for the proper functioning of the national economy. Sectors such as construction, chemicals, automotive, electronics, aerospace, mechanical engineering are all depended on access to raw materials.

The process of utilization of raw materials is currently governed by legislative standards that divide bearings into two categories - exclusive and non-exclusive bearings. Nonexclusive bearings are characterized by attributes property that is assigned to the land. Exclusive bearings are part of the mineral wealth of the state and under the Constitution they are the property of States, what is invariable. Effectiveness of the use of state property is interpreted through rationality. Since mineral resources are non-renewable, the state takes care of their economical use in order to ensure the conservation and rational utilization of

\footnotetext{
* Corresponding author: michal.cehlar@tuke.sk
} 
mineral resources as a property of the Slovak Republic, together with respect for the principles of sustainable development.

From raw materials policy strategy follows that an important and necessary condition for the smooth development of the Slovak economy, as primary inputs in the production process are mineral resources. As it was mentioned, under Article 4 of the Constitution, the domestic mineral resources are owned by the State. Since it is non-renewable, they must be protected effectively. Achieve this objective is monitored by raw material policy, which defines the goals of the company in the use of domestic mineral resources in response to the long-term needs of economic and social development of the society with regard to the environmental aspects of sustainable development, also covering geological research and exploration and exploitation of proven reserves of minerals [5], [7].

Geological structure of Slovakia is due to geological diversity and rich mineral deposits an interesting site for the location of the project based on the exploration and subsequent exploitation of mineral resources. A change of geopolitical situation, application of new technologies in the industry resulting in different economy of mineral deposits resulted in current revival of mining activities after their recession during the last few decades in the Slovakia.

\subsection{Raw materials policy of the Slovak republic}

The raw material policy is a policy of how to dispose with raw materials. The strategic view has to be seen in the context of the importance of raw materials for the development of the country and its raw material security. A vital condition for the development of the country is the availability of raw materials that fulfill the complex requirements of the society including economical, environmental and social ones. The use of own resources is both the most economical and ignore this option would be denying ownership, which is included in the Constitution.

The main content of the raw material policy of the country is the analysis of domestic resources and determination of the rules for the protection and prudent use of mineral resources of the country according to the principles of sustainable development. Because the extraction of raw materials for different branches of industry has a positive effect on the economic growth of the country, the development of a proper raw material policy is of outmost interest of the Slovakia [8].

\section{Model of optimal use of the resource base}

Model of the optimal use of the resource base based on the above mentioned facts and selected economic instruments can be divided into three parts:

1 Model for the assessment of the project of geological exploration;

2 Model for the assessment of the project of mining;

3 Model for the assessment of the project of mining on the environment.

Model for the assessment of the project of geological exploration is an important phase of the initiation of the complex mining project. The whole model is a functional process of assessment of deposits while besides the natural - geological conditions it respects the laws of behaviour of the capital, businesses and public authorities, which are regulated by the relevant legislation.

The model makes possibility to assess whether it is possible to assemble a functional unit and thus evaluate the success of the geological project as a prerequisite of exploitability deposits. The role of regions, in this case, is given only by the possibility to approve or not the zoning plan. If there is no appreciation of the deposits, through the extraction and use of effects for the region, the summary of positive and negative effects for 
the region cannot be estimated. Thus, this model serves as an advance preparation for the evaluation of deposits, so it should have an irreplaceable role in mineral policy making.

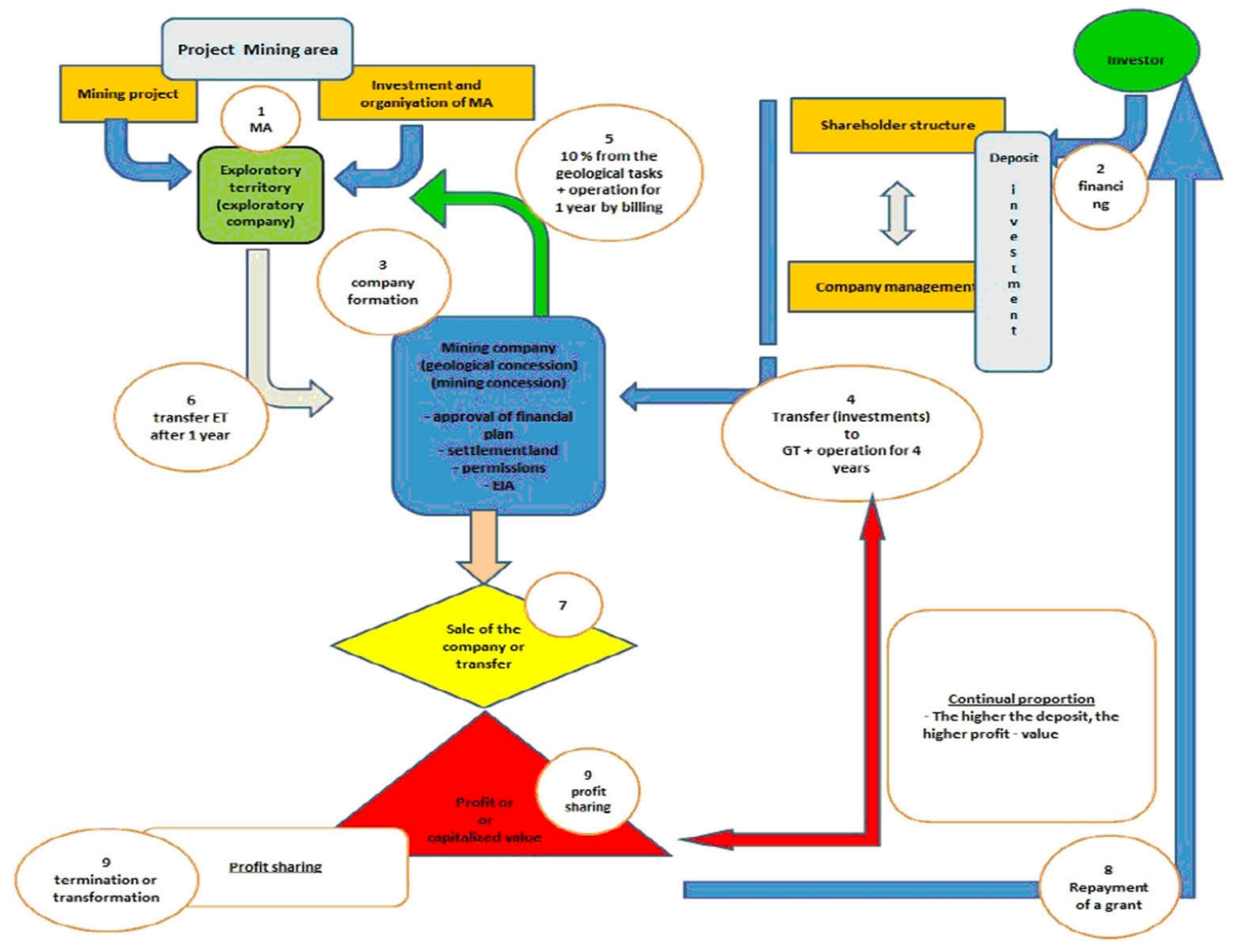

Fig. 1 Model for the assessment of the project of mining

Model for the assessment of the project of mining is an essential part of the evaluation of the optimal use of the resource. The assesment involves several parameters including regional policy for raw material utilization. The absence of this policy may cause in improper decisions, which often are in conflict from the perspective of sustainable development impacting other industries and the service sector. The role of the region, in this case, is again given only by the possibility to approve or not the zoning plan for using the deposits. A more effective tool for decision making is the fact that regional territorial plan is then binding for smaller spatial plans. This affects the representatives of the municipalities, which are parties in decision-making and allocation of mining licenses.

Then, managing conflicts of interest with contracts or sale of the land brings a strong regional charge. This task is not only indirect from the effective point of view, but there is already a recovery of the deposit by the extraction and use of effects for the region, which can be positive and negative. Thus, this model is essential for the evaluation of deposits and in the processing of raw materials policy of the region and should have an irreplaceable role. Both models, in combination with regional development policies materialised in the form of land-use decisions, are the basic structure for objective raw materials policy development of the region.

In contrast to the current state, the deposit is regarded as a resource, value that can only be assessed in relation to the project and its utilisation. 


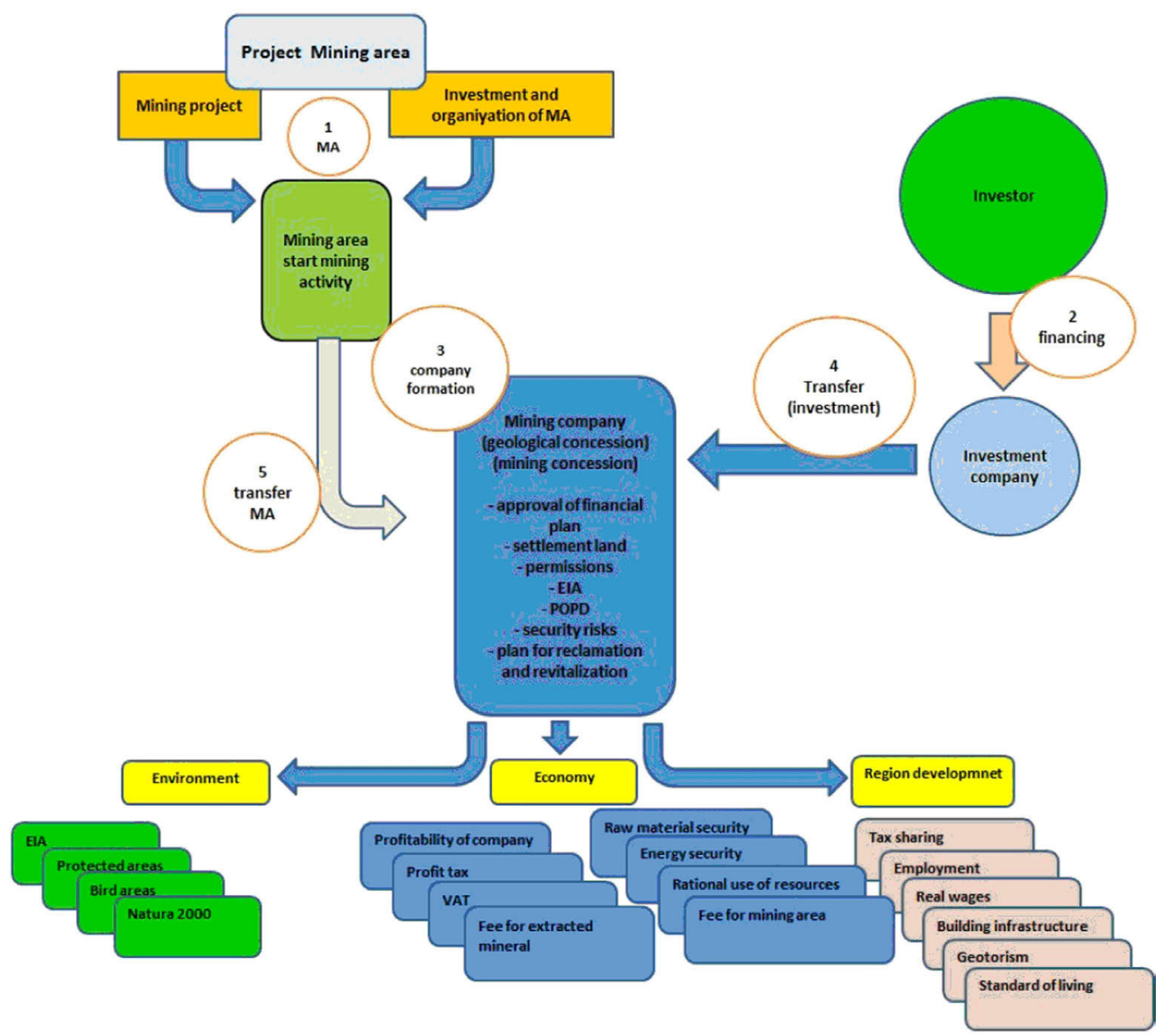

Fig. 2 Model for the assessment of the project of mining

The model for the assessment of the project of mining (Fig. 2) to the environment is closely linked to EIA (Environmental Impact Assessment). The purpose of EIA is to identify, describe and assess the direct and indirect impacts of the proposed mining on the environment, clarify and compare advantages and disadvantages of the proposed mining, including its variants, even compared to the zero option, identify measures to prevent pollution of the environment, mitigate pollution environment, or prevent damaging the environment, get a professional basis for the issuing of a mining permit under special regulations (Pavolová et al., 2012).

\subsection{The concept of raw materials policy of Košice region}

The concept of raw materials policy of Košice region is a tool for the rational use of mineral resources and for supporting the development of the region while respecting sustainable development with strict respect to the environmental protection. It means to find an optimal way of using, in which the miners are technically able to mine mineral deposits, technologically process material and economically realise all the works up to the location of raw materials in the market.

The concept of the raw material policy is a model that includes:

- legislative division of raw materials (exclusive + non-exclusive deposits), 
- assessment factors of raw materials - legislative, economic, environmental, technological, social and mine-technological and autonomous skills that represent working group composed of representatives of organisations that have a real impact on the decisionmaking process for the authorization of exploration or mining activities.

- outputs of the concept of raw materials policy:

a) the environmental impacts of the resource base of the Košice region,

b) the economic impact of the use of the resource base of the Košice region,

c) social impacts of the resource base of the Košice region,

d) development of the Košice region in a wider context.

These outputs are the main arguments for their incorporation in the process of amending and approving the zoning region plan and then to the land use plans of individual towns and villages. The model of the conception of raw material policy is a process that should occur in the sequence as indicated in the Figure 3. The fundamental facts are competences.

The result of objectification is essentially the division of mineral deposits on the concept of usable and unusable. Usability and unusability depend on factors that are part of the evaluation of mineral deposits: price, production costs, investment costs, environmental and social requirements and resource availability by size and structure. It follows that this process needs to be updated, for what is the concept of model-making raw materials policy of the region prepared.

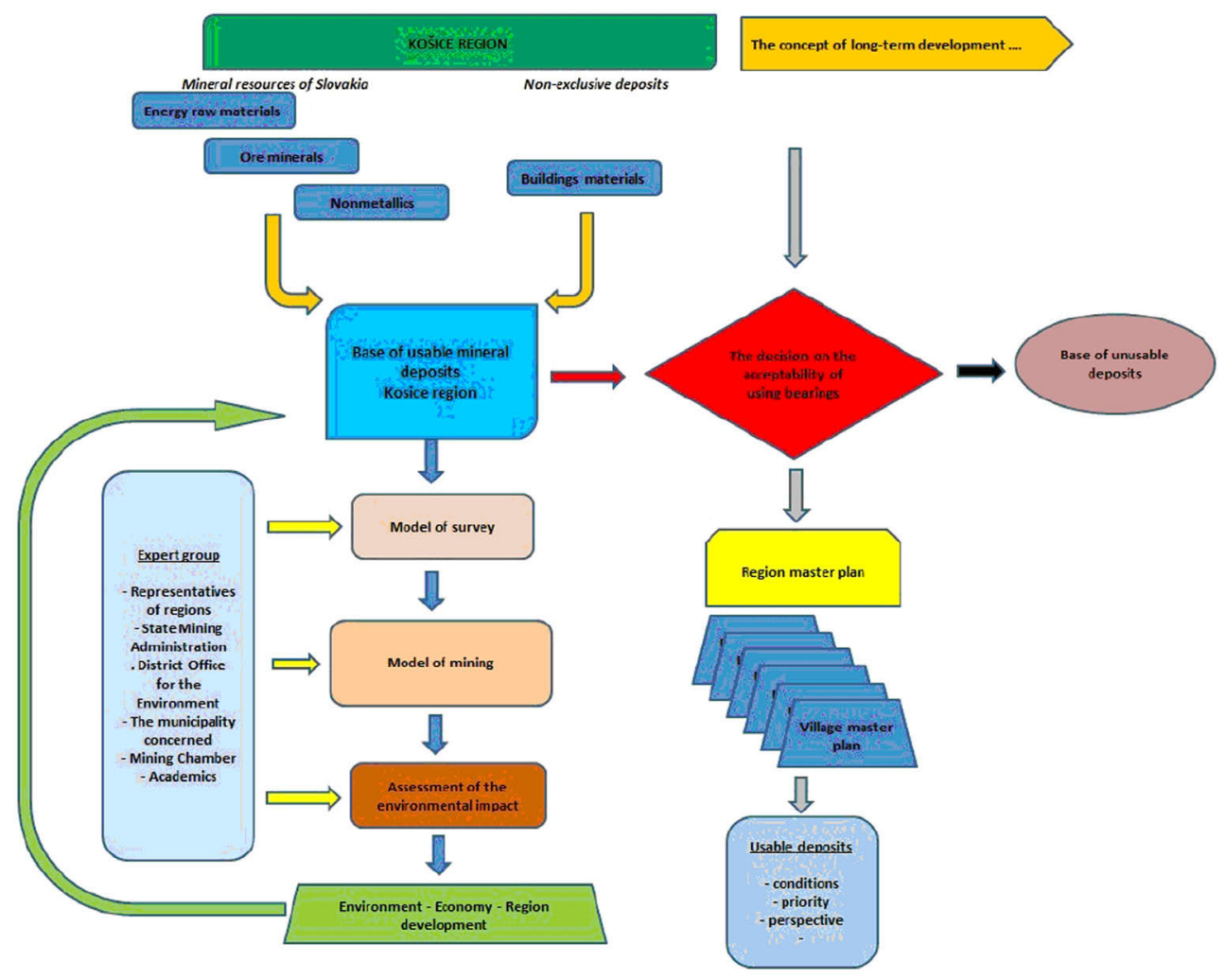

Fig. 3 The concept of raw materials policy Košice region 


\section{Verification of the model - assessment process}

Assessment approach is based on three assumptions. The first is that the economic aspects are assessable through the evaluation model, which is given by the methodology of discounted cash flow. This methodology is officially used to assess the economic efficiency of the relative "value of bearing in the time period of preparing plan for mining development versus size and structure of the planned investment vehicles for the mining and mineral processing in the selected time period, taking into account the capacity of business and economic conditions - evaluation of bearing.

The second assumption are the environmental aspects which are assessable through the model of the impact assessment EIA extractive activities in accordance with Act No. 24/2006 Coll., where is also incorporated a public participation as an important aspect of democracy in decision-making regional governance.

Finally, the third assumption of the concepts is verification for which it was selected case study assessment of regional impacts of mining and processing of gold-bearing ore on public finances.

\subsection{Economic and social assessment of the investment}

Case study focuses on the analysis of macroeconomic parameters considered for the project in gold mining. It deals with the evaluation of benefits for state, regional and project implementers. The study aims to assess the possible implementation of the mining project by the verification of the model. Delivereably of the study case is an expert support for decision to allow or disallow the realization, respectively inclusion in a portfolio bearing deposits, which should be useful in terms of making the raw material policy of region. Mining project is a demanding not only because of expertise but also because of the the economic side. The basic element is particularly high initial investment and subsequent benefits, both social and economical for the state, region and project implementers for compliance with the high standards of environmental area, set by the legislation.

\subsubsection{Geological background}

The study area is built up by the Miocene volcanic extrusions having dome-like structure and composed of amfibolitic andesite. The gold mineralization that is the target of mining activity, is associated with quartzite and forms vein-type mineralization. The ore body has a vertical to subvertical position and widens toward depth.

The ore zones are characteristic by increased occurrence of $\mathrm{Zn}$ and $\mathrm{Cu}$. The accessory minerals are magnetite, pyrite, chalkopyrite and molybdenite. The total geological reserves for the studied deposite were calculated as 140200000 tons of ore with mean content of gold $0.57 \mathrm{~g} / \mathrm{t}$.

Following is the geological structure shown on the map of the relevant area (Fig. 4). Overview of the free available reserves are shown in the Tab. 1 as well as free reserves not available shown in Tab. 2.

Tab. 1 Free available reserves [2]

\begin{tabular}{|l|l|l|l|l|}
\hline $\begin{array}{l}\text { Category } \\
\text { of reserves }\end{array}$ & $\begin{array}{l}\text { Number of } \\
\text { blocks }\end{array}$ & $\begin{array}{l}\text { Amount of reserves } \\
\text { (thsousands of tons) }\end{array}$ & $\begin{array}{l}\text { Mean quality } \\
\text { (g/t) }\end{array}$ & Utilization \\
\hline $\mathbf{Z 2}$ & 1 & 17031 & 0.82 & $\begin{array}{l}\text { Production } \mathrm{Au} \\
\text { (bullion) }\end{array}$ \\
\hline $\mathbf{Z 3}$ & 1 & 14497 & 0.76 & $\begin{array}{l}\text { Production } \mathrm{Au} \\
\text { (bullion) }\end{array}$ \\
\hline $\mathbf{Z - 2}+\mathbf{Z - 3}$ total: & $\mathbf{3 1 5 2 8}$ & $\mathbf{0 . 7 9 2}$ & \\
\hline
\end{tabular}




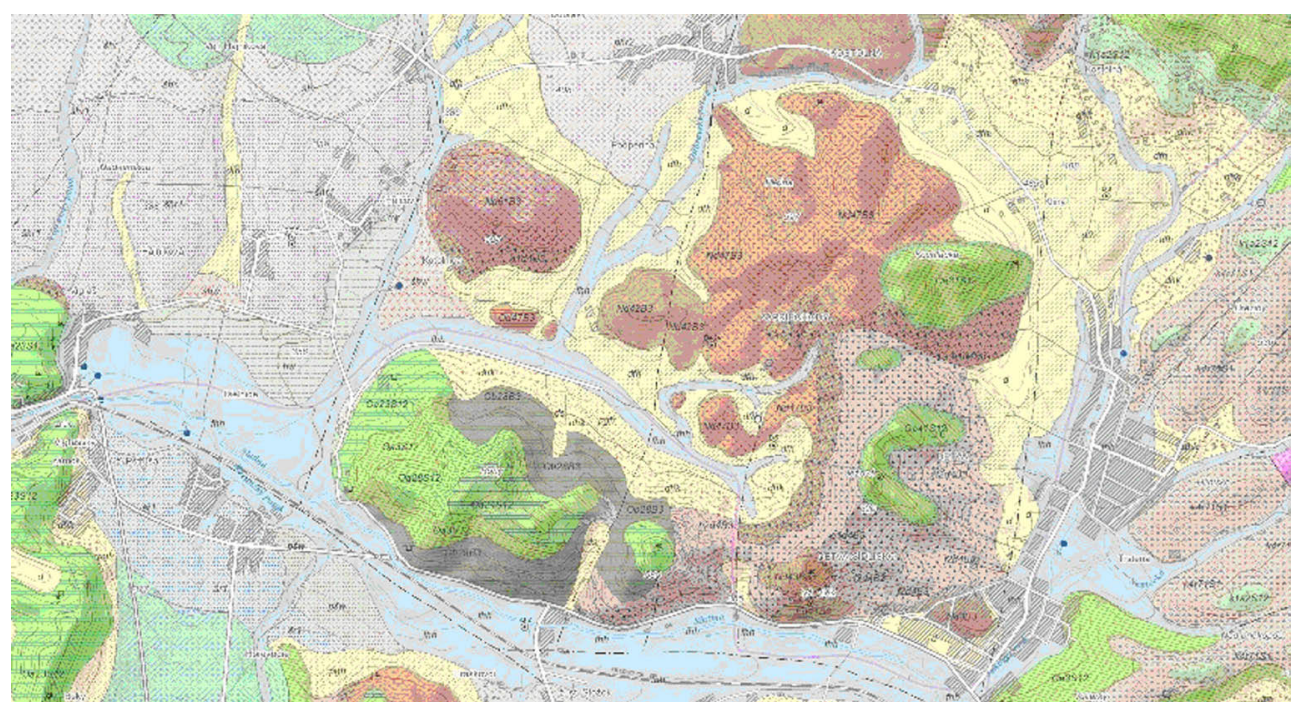

Fig. 4. Geological structure of the site area of interest and the wider surroundings [2], [3]

Tab. 2 Free reserves not available [2]

\begin{tabular}{|l|l|l|l|}
\hline $\begin{array}{l}\text { Category of } \\
\text { reserves }\end{array}$ & Number of blocks & $\begin{array}{l}\text { Amount of reserves } \\
\text { (thousands of tons) }\end{array}$ & $\begin{array}{l}\text { Mean quality } \\
\text { (g/t) }\end{array}$ \\
\hline $\mathbf{Z 3}$ & 1 & 108742 & 0.508 \\
\hline
\end{tabular}

Overburden abover the reserve block represents totaly an amount of $892155 \mathrm{~m}^{3}$.

\subsubsection{Social-economic parameters of the project}

The situation in ore mining in Slovakia is in critical condition. Over the last five years there has been a tenfold decrease in ore mining and production of products.

Project of gold ore bearing has potential for development as the economic position of the region as well as improving the socio-economic status. At the same time launching the project would have to support production in metal processing and employment of staff in the sector.

The development of prices on the world markets especially in the field of precious metals indicates an increase in demand for these products what has an impact on the preparation and implementation of such projects.

During project implementation at mining area foresees the creation of 220 direct jobs - management positions of control commercial and economic matters, technical and economic, technicians and other staff. Implementation of the project will be given the potential to create more jobs and indirectly. These positions will mainly be related to the provision of services.

The clasification of employees will be implemented based on the organizational structure of the organization. Conducting the necessary geological and technical mining and other management and leadership activities require professional qualifications of staff.

Mining company can create employment in the standard working environment with the assessment of employees based on their qualifications, quality of work, and the degree of difficulty of the work respecting the legislative requirements in the field of labor law.

Estimated average amount of gross wages of employees is in the amount of $€ 1,600$ / month. 
Tab. 3 Ore production in Slovakia

\begin{tabular}{|c|c|c|c|c|c|c|c|c|c|c|c|}
\hline \multirow[t]{2}{*}{ Factory } & \multicolumn{5}{|c|}{ Ore mining (kt) } & & \multicolumn{5}{|c|}{ Production of concentrates $(\mathrm{t}, \mathbf{k g})$} \\
\hline & 2005 & 2006 & 2007 & 2008 & 2009 & & 2005 & 2006 & 2007 & 2008 & 2009 \\
\hline \multirow[t]{4}{*}{ Rudňany } & \multirow{4}{*}{29.1} & \multirow[t]{4}{*}{62.1} & \multirow[t]{4}{*}{25.9} & \multirow{4}{*}{20.6} & \multirow[t]{4}{*}{$2 ., 9$} & $\mathrm{Fe}$ & & & & & \\
\hline & & & & & & $\mathrm{Cu}$ & & & & & \\
\hline & & & & & & $\mathrm{Hg}$ & & & & & \\
\hline & & & & & & BaSo4 & 4.2 & 25.8 & 12.5 & 7.3 & 8.628 \\
\hline $\begin{array}{l}\text { Nižná } \\
\text { Slaná }\end{array}$ & 603.5 & 660.4 & 640.3 & 443.8 & 0 & $\mathrm{Fe}$ & 258.5 & 310.6 & 348.5 & 180.6 & \\
\hline $\begin{array}{l}\text { Slovenská } \\
\text { banská } \\
\text { Ltd. } \\
\text { Hodruša } \\
\text { Hámre }\end{array}$ & 19.3 & 19.5 & 15 & 14.74 & 34.99 & $\mathrm{X}^{*}$ & 0.4 & 0.4 & 0.4 & 0.465 & 0.741 \\
\hline \multirow[t]{8}{*}{ Together } & \multirow[t]{8}{*}{651.9} & \multirow[t]{8}{*}{742} & \multirow[t]{8}{*}{681.2} & \multirow[t]{8}{*}{479.14} & \multirow{8}{*}{64.89} & $\mathrm{Fe}$ & 258.5 & 310.6 & 348.5 & 180.6 & \\
\hline & & & & & & $\mathrm{Cu}$ & 4.4 & 4.4 & 2.1 & & 14.28 \\
\hline & & & & & & $\mathrm{Hg}$ & & & & 6.26 & \\
\hline & & & & & & BaSo4 & 4.2 & 25.8 & 12.5 & 7.3 & 8.628 \\
\hline & & & & & & $\mathrm{Au}$ & 108.6 & 83.7 & 92 & & 346.11 \\
\hline & & & & & & $\mathrm{Ag}$ & 65.2 & 74.4 & 50.1 & 198.45 & 201.07 \\
\hline & & & & & & $\mathrm{Pb}$ & 23.2 & 15.1 & 11.4 & 104.86 & 62.514 \\
\hline & & & & & & $\mathrm{Zn}$ & 20.9 & 21 & 11.6 & 30.019 & 54.104 \\
\hline
\end{tabular}

Total average annual income of the state formed by tax of employer, tax of employee and payroll tax represents the amount of 2,748 million $€$ at 220 employees.

We need to take into account the telegraph arrival curve associated with job creation. It is believed that these average values representing the socio - economic parameters of the project will be achieved in the second year of the project.

Tab. 4 Overview of developments in the average monthly wage and the minimum wage [4]

\begin{tabular}{|c|c|c|c|c|c|}
\hline Year & \multicolumn{3}{|c|}{ The gross monthly minimum wage } & $\begin{array}{c}\text { Statistically recorded } \\
\text { average monthly wage } \\
\text { for the year (PM) }\end{array}$ & $\begin{array}{c}\text { MM/ } \\
\text { /PM }\end{array}$ \\
\hline & E/ month & Valid from & $\begin{array}{c}\text { According the } \\
\text { regulation }\end{array}$ & $\boldsymbol{€}$ monthly & $\%$ \\
\hline $\mathbf{2 0 1 6}$ & 405 & 1.1 .2016 & $279 / 2015$ & & \\
\hline $\mathbf{2 0 1 5}$ & 380 & 1.1 .2015 & $297 / 2014$ Z.z. & & \\
\hline $\mathbf{2 0 1 4}$ & 352 & 1.1 .2014 & $321 / 2013$ Z. z. & 858,00 & 41,03 \\
\hline $\mathbf{2 0 1 3}$ & 337.70 & 1.1 .2013 & $326 / 2012$ Z. z. & 824,00 & 40,98 \\
\hline $\mathbf{2 0 1 2}$ & 327.20 & 1.1 .2012 & $343 / 2011$ Z. z. & 805,00 & 40,65 \\
\hline $\mathbf{2 0 1 1}$ & 317.00 & 1.1 .2011 & $408 / 2010$ Z. z. & 786,00 & 40,33 \\
\hline $\mathbf{2 0 1 0}$ & 307.70 & 1.1 .2010 & $441 / 2009$ Z. z. & 769,00 & 40,01 \\
\hline $\mathbf{2 0 0 9}$ & 295.50 & 1.1 .2009 & $422 / 2008$ Z. z. & 744,50 & 39,69 \\
\hline $\mathbf{2 0 0 8}$ & 268.87 & 1.2 .2008 & $663 / 2007$ Z. z. & 723,03 & 37,19 \\
\hline $\mathbf{2 0 0 7}$ & 268.87 & 1.10 .2007 & $450 / 2007$ Z. z. & 668,72 & 40,21 \\
\hline $\mathbf{2 0 0 6}$ & 252.27 & 1.10 .2006 & $540 / 2006$ Z. z. & 622,75 & 40,51 \\
\hline
\end{tabular}




\subsubsection{Social-economic assessment of the project}

For the evaluation of the project - gold-bearing ore as a means for assessing the socioeconomic assessment of the project it is necessary to evaluate the overall economics of the project. It consists of projected investment costs, the fixed and variable costs, which are known at the moment of evaluation of the project, the anticipated yields and so on. In summary, this is a project evaluation in the mined gold ore. Determine the economic efficiency of financial investments of extraction and processing technology in the deposit is made by assessing the efficiency of investment. The overall parameters of the volume of extractable reserves in respect of the mining-technical conditions, environmental and economic conditions are listed below:

- The total volume of extracted raw materials $54000 \mathrm{kt}$

- The total volume of ore: $23000 \mathrm{kt}$

- Average annual extraction of $5000 \mathrm{kt}$

- The average annual volume of extracted ore $2130 \mathrm{kt}$

- The average annual yield of gold: $2343 \mathrm{~kg}$

The total amount of probable reserves of gold-bearing ore at the deposit is 23 million. ton and at this annual extraction represents bearing life about 10 years. To access the reserves of mineral raw materials for mining should be carried out preparatory work and uncovering. To increase the volume of reserves suitable for mining-technical application it is necessary to continue the geological survey to increase the exploration of deposits and reclassification from the list of non-balanced to balanced reserves. This changes the above contemplated amount of total mined raw materials and other parameters.

To start the project is required investment of $€ 45,536$ mil. $€$. The successful implementation of the project it is needed to invest the financial resources in the total amount of 45,536 mil. $€$ with the timeline of 2.5 years.

Annual direct (variable) and indirect (fixed) costs of production from level of the year 2010 are composed of the following items (calculated at an average rate of annual extraction of 5 mil. Tonnes per year):

- preparatory work consisting of: construction of transport routes,

- uncovering work : overburden works, quarry face, dewatering

- extraction of raw materials: primary and secondary rock disintegration, transport of raw material

- treatment and refining: mechanical treatment, chemical-technology treatment etc.

Taking into account the annual production is the direct production costs determined on the basis of the above at: $€ 2.35 / \mathrm{t}$ mined of raw material. Mentioned direct production costs $(€ 2.35 / \mathrm{t}$ ) does not contain the labor and financial costs as well as the depreciation. They are in the methodology calculated separately.

The average selling price per $1 \mathrm{oz}$ of mined gold will be fixed by contract price, dependent of contracted quantity and quality of the product and also on the price of gold on world commodity market and exchange rate in $€ /$ USD. This study takes into account the price of gold based on the world stock exchanges values, where the date of 10.11.2010 the price is $€ 960 / \mathrm{oz}$ in the amount of $\$ 1.4 / €$. The average selling price is $€ 30.87 / \mathrm{g}$ of Au. Determination of the final price will be the responsibility of the sales department and statutory company [2].

\subsubsection{Economic assessment of the project}

Overall layout drawing of funds in time is as follows: $100 \%$ in the first year (investment of own funds in the amount of 45.586 mil. $€$ ). Based on the data declared by the National Bank of Slovakia is done updating economic parameters. For the project of gold-bearing ore mined at the relevant site is a summary measure of updating the value of $6 \%$. 
In the case of "the payment of fees for extracted mineral", which regulated the Ministry of Economy in the range of $0-10 \%$ it is considered a limit of $5 \%$, according to NVSR no. $50 / 2002$ Coll. This value corresponds to the value of the mineral and its method of production.

Income tax is at $19 \%$, consisting of a percentage level of 2011 , the implementation period for the assessment of deposits for the purposes of exploitation, the period of execution of the decision.

Based on the evaluating of deposit, available reserves in terms of planned mining activities in the mining area referring to state the following facts:

1.Development of Cash Flow (CF) - In the first two years shows a negative value (investment and to modernize and increase the capacity of technology), then in the third year and the following years (with respect to the total volume of extraction and currently proven reserves), reaching a positive value. The actual investment in the project mining and processing of gold ore at those sites is negligible compared to the turnover. Investments (45 mil. $€$ ) needed to provide property rights to movable and immovable property, to obtain the mining area to build the plant and the related financing operations are considered from its own resources. An increase is noticeable in the 6 th and 7 th year of the project. This sharp upward trend is also provable for seven years horizon, but this is conditional upon subsequent geological survey, which for the purposes of geological law must result in approvals of new, workable reserves. The result is the ability to project self-financing and thus the operate the mining project from its own resources.

Present value (PV), without taking into account the time of updating reaches after expiration the period related to the 2010 during the extraction will be carried out according to the plans submitted is at level of $201608221-€$.

2. Value of the deposit (Net Profit Value) - defined by the referred exploration area, with a time horizon of assessment to 10 years, capacity of 5 million ton of minerals utilized by this project, with regard of conditions of 2010 and planned finish of investment plan; determined on 120171320 - $€$.

\section{Conclusion}

The issue of exploitation of mineral resources of Slovakia is fully reflected in accordance with applicable legislation in its management. This treatment is documentable through processes that are embodied in raw materials policy. Although this level of law is prepared, it contains only general declarations that without institutional instruments can not be effectively used and implemented. Nevertheless gives a framework which is binding and inspiring.

Taking over decision-making powers and brought with it the responsibility for decisionmaking. Just as it is the case in connection with the decision of the zoning plan to be adopted at the level of municipal governments and also municipalities and cities. Deposit utilization and consent to it is fully within the competence of the higher territorial unit and in approving the amended land use plan and the village or town for the same reason and in addition from the relevant municipality or city is subject to the parties in the selection and approval of the mining and mining area.

Global importance of raw materials is obvious interpretation of their impact on the world economy, the national economy and regional economy. Cost of raw material availability was reflected even through the availability of energy resources, which has occurred in the recent past and the impact on the economy across Europe were apparent.

Raw material security is all about availability and our own raw material base is more important than is apparent today. The European Commission started works on mineral policy in last years. In 2008 launched the EU Raw Materials Initiative in order to ensure 
security of raw material supply for its economic growth [11]. European Union can not be restricted or disfavoured by aspect of inefficient or incorrect decisions of Member States. Especially countries that do not have a direct impact on its raw material base and keep it deformed often by tendentious views on raw material basis and its use.

The decision-making model that combines information, competence and strategy is of crucial importance to maintain the ability to decide on their property. Decide competently, professionally, responsibly and at the same time take into account in this process specifics deposit (its size, quality, geotechnical conditions of mining, market position, location, complexity of technology, mining method, number of employees, their qualifications, risks, management of mining and processing of of raw material, etc.), the specifics of the region (flora and fauna, protected areas, industrial activity, age and educational structure of population, employment, architecture, recreation, development plans, etc.), specifications interests of the State as owner (raw material security, Non-renewability of the source, the strategic position of source income of the state budget, etc.) and the specifics of miners (know-how, management skills, marketing links, financial opportunities, market share, etc).

The model provides the opportunity to work with known facts or contrary extract facts that are required, for example, the future potential miners. Success of application depends only on the willingness to take a decision to address the region's raw materials at conception, conception process raw materials policy of the region and apply it effectively in decision-making.

\section{References}

1. Pavolová, H., Cehlár, M., Soušek, R., Vplyv antropogénnych činností na kvalitu životného prostredia (Institut Jana Pernera, 2012)

2. AMC Consultants (UK) Limited: Biely Vrch Scoping Study. Eastern Meditteranean Resources Slovakia, s.r.o. 2010.

3. Hlavný banský úrad. (2016). Evidencia dobývacích priestorov: Obvodný banský úrad v Košiciach. Retrieved February 15, 2016 from http://www.hbu.sk

4. Institute of Informatics and Statistics (2016). Retrieved February 15, 2016 from http://www.infostat.sk

5. Aktualizácia surovinovej politiky Slovenskej republiky pre oblast' nerastných surovín. MH SR, Uznesenie vlády č. 661/1995 aktualizovaný materiál a legislatíva k 31.12. 2003.

6. Cavender, B.: Determination of the optimum lifetime of a mining project using discounted cash-flow and option pricing techniques (Mining Engineering, 1992)

7. The mineral policy and joining of European Union. Retrieved March 15, 2017 from http://library.envifor.eu:8282/greenstone/collect/PDF/SK_000927.pdf

8. Puzder M., Koščová M., XVIII International Coal Preparation Congress, 457, 2016

9. Glöser-Chahoud S., Espinoza L, Walz R., Faulstich M., Resources, 5, 45 (2015)

10. Achzet B., Helbig Ch., Resources Policy, 38(4), 435 (2013)

11. Kulczycka J., Kudelko J., Wirth H. Role and aim of mineral raw materials policy presented in national strategic documents. Retrieved March 15, 2017 from https://www.researchgate.net/publication/302193446_Role_and_aim_of_mineral_raw_ materials_policy_presented_in_national_strategic_documents 